\title{
Increase in $\beta$-Amyloid Levels in Cerebrospinal Fluid of Children with Down Syndrome
}

\author{
Hillevi Englund ${ }^{a} \quad$ Göran Annerén $^{\mathrm{b}}$ Jan Gustafsson ${ }^{c}$ Ulrika Wester ${ }^{c}$ \\ Jens Wiltfang ${ }^{\mathrm{e}}$ Lars Lannfelt $^{\mathrm{a}}$ Kaj Blennow $^{\mathrm{d}}$ Kina Höglund $^{\mathrm{d}}$ \\ ${ }^{a}$ Department of Public Health and Caring Sciences, Section of Molecular Geriatrics, and ${ }^{b}$ Department of Genetics \\ and Pathology, Unit of Clinical Genetics, Uppsala University, 'Department of Women's and Children's Health, \\ Uppsala University Children's Hospital, Uppsala, and ' Department of Neuroscience and Physiology, \\ Sahlgrenska Academy, Göteborg University, Göteborg, Sweden; ${ }^{\mathrm{e}}$ Molecular Neurobiology Lab, Department of \\ Psychiatry and Psychotherapy, University of Erlangen-Nuremberg, Erlangen, Germany
}

\section{Key Words}

Alzheimer's disease $\cdot$ Down syndrome $\cdot$ Amyloid- $\beta \cdot$ Tau $\cdot$ Cerebrospinal fluid the levels of total tau decreased and phosphorylated tau remained unchanged. This observation further strengthens the theory of $A \beta$ pathology preceding tau pathology in $A D$.

Copyright $\odot 2007$ S. Karger AG, Basel

\begin{abstract}
Background: Individuals with Down syndrome (DS) invariably develop Alzheimer's disease (AD) during their life span. It is therefore of importance to study young DS patients when trying to elucidate early events in AD pathogenesis. Aim: To investigate how levels of different amyloid- $\beta(A \beta)$ peptides, as well as tau and phosphorylated tau, in cerebrospinal fluid (CSF) from children with DS change over time. The first CSF sample was taken at 8 months and the following two samples at 20-40 and 54 months of age. Results: Individual levels of the $A \beta$ peptides, as well as total $A \beta$ levels in CSF increased over time when measured with Western blot. Tau in CSF decreased whereas there was no change in levels of phosphorylated tau over time. Conclusion: The increasing levels of A $\beta$ in CSF during early childhood of DS patients observed in this study are probably due to the trisomy of the $A \beta$ precursor APP, which leads to an overproduction of $A \beta$. Despite the increased CSF concentrations of $A \beta$, there were no signs of an AD-indicating tau pattern in CSF, since
\end{abstract}

\section{KARGER}

Fax +4161306 1234

E-Mail karger@karger.ch

www.karger.com (c) 2007 S. Karger AG, Basel

$1420-8008 / 07 / 0245-0369 \$ 23.50 / 0$

Accessible online at:

www.karger.com/dem

\section{Introduction}

Down syndrome (DS) is the most common genetic disorder with mental retardation and is caused by trisomy 21. By the age of 40, virtually all adults with DS fulfill the neuropathological criteria for Alzheimer's disease (AD) diagnosis [1-3], displaying a cortical pathology with abundant senile plaques of aggregated amyloid- $\beta$ (A $\beta$ ) peptides and neurofibrillary tangles composed of hyperphosphorylated tau [4]. According to the amyloid cascade hypothesis [5], AD is caused by an abnormal accumulation of $A \beta$ during life, which leads to plaque formation with neurodegeneration and formation of tangles as downstream events.

The localization of the $A \beta$ precursor gene - amyloid precursor protein (APP) gene - on chromosome 21 [6] leads to a lifelong overexpression of APP in patients with $D S$, resulting in an overproduction of $A \beta$ during life, 
Table 1. Demographic data

\begin{tabular}{lllll}
\hline & Age, months & GH treatment & Western blot analysis & xMAP analysis \\
\hline Sample 1 & $8(8-10)$ & before treatment & $\mathrm{n}=9$ & $\mathrm{n}=8$ \\
Sample 2 & $20(19-21)$ and 45 (44-46) & during treatment & $\mathrm{n}=11$ & $\mathrm{n}=9$ \\
Sample 3 & $56(55-56)$ & 1 year after end of treatment & $\mathrm{n}=4$ & $\mathrm{n}=4$ \\
\hline
\end{tabular}

which probably explains their inevitable AD pathology [7]. The observation of a patient with DS with a partial trisomy 21 lacking the part of the $21 \mathrm{q}$ arm containing the $A P P$ gene, and who thus did not develop AD [8], further strengthens the connection between $A \beta$ formation and $A D$. It also emphasizes the need for studying young individuals with DS in search of pathogenic mechanisms early in $\mathrm{AD}$.

Measuring how levels of soluble $A \beta$ peptides in cerebrospinal fluid (CSF), total tau (t-tau) and tau phosphorylated at threonine 181 ( $\mathrm{p}$-tau) change over time in very young individuals with DS could help us understand early events in the pathogenesis of AD. Such measurements could also unravel if the constant overproduction of $A \beta$ expected in individuals with DS could result in the same $A \beta, t$-tau and $p$-tau patterns seen in CSF from elderly individuals with sporadic $\mathrm{AD}[9,10]$.

In this study, biomarkers of $\mathrm{AD}$ were analyzed in longitudinally taken CSF samples from children with DS, with the first sample taken at 8 months of age and the last at 54 months. Levels of $A \beta_{1-37 / 38 / 39 / 40}$ and $A \beta_{42}$, forming the disease-specific $A \beta$ pattern [9], were measured by Western blot. Concentrations of t-tau, $p$-tau and $A \beta_{1-42}$ were measured by the xMAP technology. CSF levels of total $A \beta$, as well as individual levels of all $A \beta$ peptides, increased during the first 54 months of life in these patients with DS. Levels of $t$-tau decreased while levels of p-tau remained unchanged.

\section{Materials and Methods}

The present investigation is a substudy of a previously published investigation, in which young patients with DS were treated with growth hormone $(\mathrm{GH})$ for 3 years starting at 6-9 months of age [11]. The local ethics committee at Uppsala University, Uppsala, Sweden, approved the study. The parents gave informed consent for their children to participate in the study, which was conducted according to the provisions of the Helsinki declaration. CSF samples were taken by lumbar puncture at 6-10 months of age (before start of $\mathrm{GH}$ treatment), at 20 and 40 months (during $\mathrm{GH}$ treatment) and at 53-54 months (1 year after finishing $\mathrm{GH}$ treatment), centrifuged to remove cell debris and stored at $-80^{\circ} \mathrm{C}$ until analysis (demographic data in table 1). Treatment with GH had a positive effect on statural growth, but neither accelerated head growth nor had any effect on mental or gross motor development. The growth velocity declined after cessation of treatment [11]. Unfortunately, there are no APOE genotypes of the individuals participating in the study. However, for patients with DS no correlation between APOE genotype and A $\beta$ levels has been observed in earlier studies [12-14].

Western blot was performed according to a previously described protocol [9]. The levels of $A \beta_{1-42}$ were also measured with the xMAP technology and the INNO-BIA AlzBio3 kit (Innogenetics) as well as t-tau and p-tau levels, as previously described [15]. Due to limited sample size not all samples were assayed using the xMAP technology.

All statistical procedures were performed using the Statistical Package for the Social Sciences 12.0.1 (SPSS for Windows). The Shapiro-Wilk test was performed to test the distribution of the data. Data were not normally distributed and since there were a limited number of longitudinal samples available from the same individual, the Mann-Whitney U test was used to compare differences between samples taken at the three different time points. Individual $\mathrm{A} \beta$ peptides were expressed as absolute $(\mathrm{ng} / \mathrm{ml})$ and relative values (as a percentage of the total $A \beta$ peptide concentration; $A \beta_{1-X} \%$, fractional $A \beta$ peptide values); $p$ values lower than 0.05 were considered significant. The ratio between $A \beta_{1-42}$ and $A \beta_{1-40}$ was calculated by dividing the level of $A \beta_{1-42}$ in each subject by $A \beta_{1-40}$ and then the ratio was multiplied by 10 [16].

\section{Results}

In the present study, we have investigated $\mathrm{AD}$ biomarkers in CSF during early childhood (8-54 months of age, demographic data presented in table 1) in individuals with DS. There was a longitudinal increase in all of the individual levels of $A \beta_{1-37 / 38 / 39 / 40}$ and $A \beta_{42}$, and thus also in total levels of $A \beta$, from 8 to 54 months of age (fig. la, b; table 2). Only levels of $A \beta_{1-37}$ and $A \beta_{1-38}$ increased significantly $(\mathrm{p}=0.05)$, while the increase was near-significant for $A \beta_{1-39}, A \beta_{40}$ and $A \beta_{42}$. There was no indication of an increased $A \beta_{1-42} / A \beta_{1-40}$ ratio (fig. 1c). Additionally, no individuals displayed an $\mathrm{AD}$-indicative peptide pattern. When comparing $A \beta_{1-42}$ levels measured by the nondenaturing xMAP technology (fig. 2a) with levels measured by the denaturing Western blot 

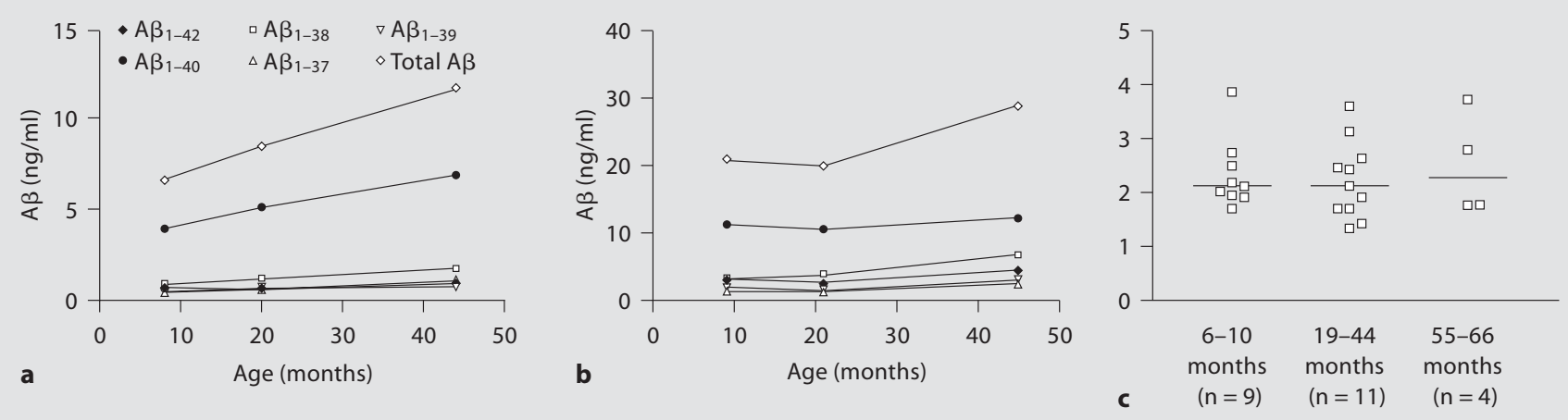

Fig. 1. Longitudinal $A \beta$ peptide measurements for 2 of the individuals showing an increase of all $A \beta$ peptides measured by Western blot $(37 / 38 / 39 / 40 / 42)$ over time $(\mathbf{a}, \mathbf{b})$, where the increase in $A \beta_{1-37}$ and $A \beta_{1-38}$ for the whole sample reached significance $(\mathrm{p}=0.05)$. The ratio $A \beta_{1-42} / A \beta_{1-40}$, shown for all individuals, is stable over time (c). Line indicates median.

Table 2. A $\beta$ peptides at $8,20-40$ and 54 months of age in CSF from infants with DS

\begin{tabular}{|c|c|c|c|c|c|c|c|c|c|c|c|c|c|c|c|c|c|c|}
\hline & \multicolumn{3}{|c|}{$\mathrm{A} \beta_{1-42}$} & \multicolumn{3}{|c|}{$\mathrm{A} \beta_{1-40}$} & \multicolumn{3}{|c|}{$A \beta_{1-38}$} & \multicolumn{3}{|c|}{$A \beta_{1-37}$} & \multicolumn{3}{|c|}{$\mathrm{A} \beta_{1-39}$} & \multicolumn{3}{|c|}{ Total A $\beta$} \\
\hline & 8 & $20-40$ & 54 & 8 & $20-40$ & 54 & 8 & $20-40$ & 54 & 8 & $20-40$ & 54 & 8 & $20-40$ & 54 & 8 & $20-40$ & 54 \\
\hline Absolute values, $\mathrm{ng} / \mathrm{ml}$ & 1.2 & 1.8 & 1.8 & 5.9 & 7.5 & 8.8 & 1.6 & 2.4 & 3.6 & 0.7 & 1.4 & 1.6 & 1.1 & 1.4 & 1.8 & 10.4 & 13.8 & 18.4 \\
\hline Percentage of total $A \beta$ & 12 & 11 & 11 & 57 & 53 & 49 & 15 & 17 & 21 & 7 & 8 & 9 & 9 & 9 & 10 & 100 & 100 & 100 \\
\hline
\end{tabular}

Results are medians.

method (fig. 2b), they display directly opposite longitudinal patterns; while Western blot-measured $A \beta_{1-42}$ levels increase over time, xMAP-measured levels decrease. Quantification of t-tau in CSF demonstrated a nonsignificant $(\mathrm{p}=0.503)$ decrease in concentration over time (fig. 3a), while no change could be observed in levels of p-tau (fig. 3b).

\section{Discussion}

With the knowledge of most patients with DS unavoidably becoming AD patients later in life, there has been an interest among $\mathrm{AD}$ researchers to use $\mathrm{DS}$ as a model in search of mechanisms causing sporadic AD. Therefore, several studies of $A D$ markers, like $A \beta$ levels in the brain, plasma and CSF, have been published. The present study is the first longitudinal study of $A \beta$ and tau levels in CSF measured in patients with DS during early childhood. Soluble $A \beta_{1-42}$ in the brain has been demonstrated to be present already from gestational week 21 in
DS fetuses, but was undetectable in age-matched controls [17]. The presence of soluble $A \beta_{1-42}$ preceded plaque formation in these DS patients, although the levels were exponentially increased in brains bearing amyloid plaques. A study of $A \beta$ concentrations in CSF from older DS individuals of different ages showed a decrease in CSF A $\beta$ between 21 and 61 years of age [18], similar to the CSF A $\beta$ decrease observed during the pathogenesis of sporadic $\mathrm{AD}$ [19-21]. A number of studies have been performed in which plasma levels of $A \beta$ in patients with DS have been investigated. In one study analyzing the levels of $A \beta_{1-42}$ in plasma from fetuses, no difference was observed between fetuses with DS and those with normal karyotype [22]. Regarding adults with DS, several reports demonstrated increased plasma levels of $\mathrm{A} \beta_{1-40}$ and $\mathrm{A} \beta_{1-42} \mathrm{com}$ pared to controls $[13,23,24]$.

The amyloid cascade hypothesis is primarily based on findings from familial AD cases where the disease-causing mutations are known to induce an increased $A \beta$ production. This is further supported by a report demonstrating that a duplication of the APP locus led to AD in 
Fig. 2. Longitudinal changes in $\operatorname{CSF} A \beta_{1-}$ ${ }_{42}$ levels analyzed with both the nondenaturing xMAP technology (a) and the denaturing Western blot method (b). Direct opposite patterns are revealed depending on the method used, indicating formation of soluble $\mathrm{A} \beta$ aggregates in CSF during this period of life. Line indicates median.

Fig. 3. CSF levels of t-tau decline during the first 54 months of life in these DS patients, however nonsignificantly ( $\mathrm{p}=$ 0.503 ) (a), whereas levels of $\mathrm{p}$-tau remain unchanged over time (b). Line indicates median.
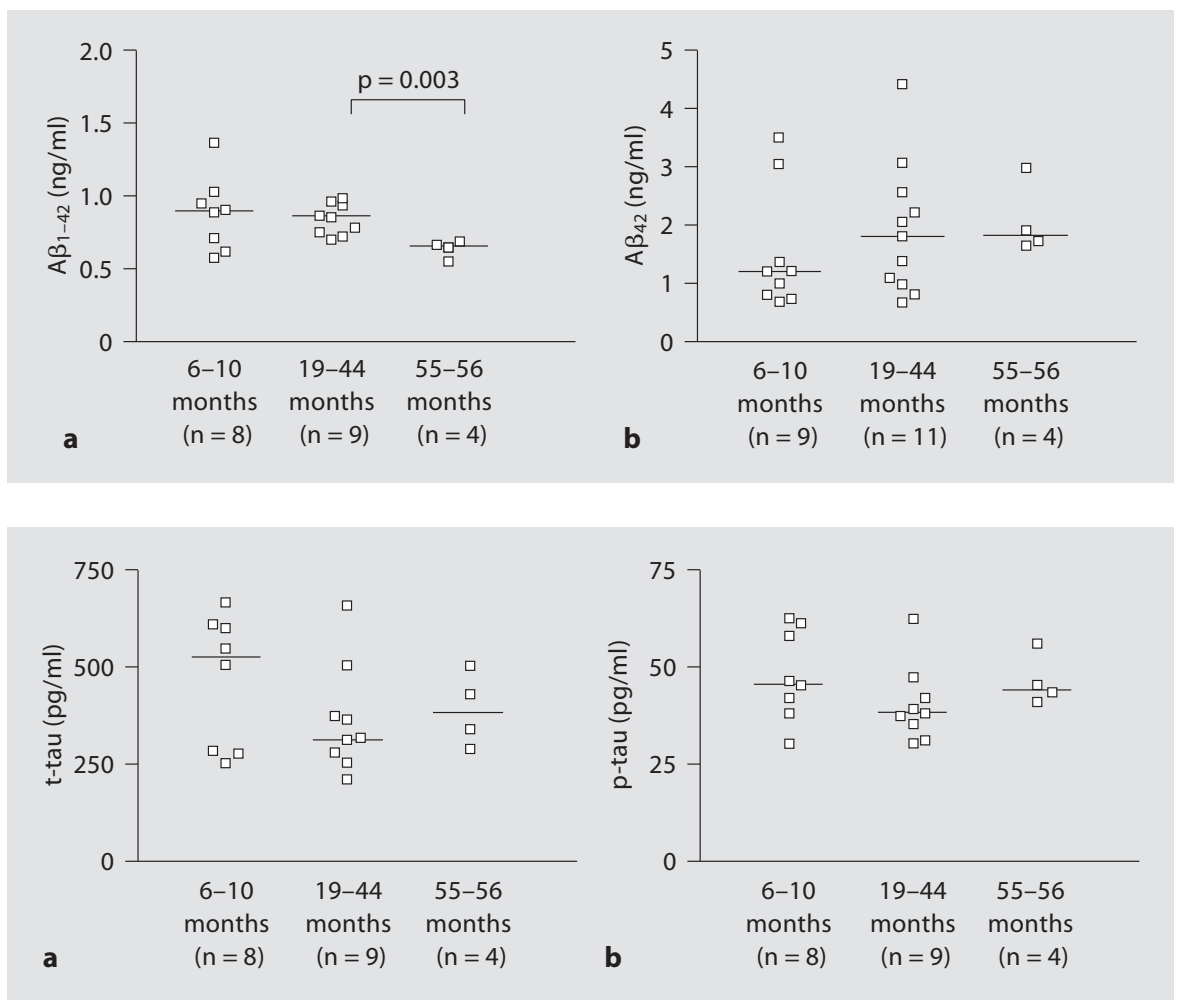

5 families, with no clinical feature of DS [25]. However, there is a lack of evidence demonstrating overproduction of $\mathrm{A} \beta$ in sporadic $\mathrm{AD}$. The $\mathrm{AD}$-specific peptide pattern found in patients with sporadic AD seems to be tightly regulated $[9,26]$, but whether there is an $A \beta$ overproduction or an impaired $\mathrm{A} \beta$ clearance causing the $\mathrm{AD}$-indicative peptide pattern is unknown. In the present study, we found no $A D$-indicative $A \beta$ pattern in individuals with DS, even though they are expected to have an overproduction of $A \beta$. If this suggests that the elevated $A \beta$ levels leading to plaque formation in sporadic $\mathrm{AD}$ are due to insufficient clearance, rather than overproduction of $A \beta$, remains to be elucidated.

Decreased levels of $A \beta_{1-42}$ in CSF, measured by ELISA, have been used as a diagnostic marker of sporadic $A D$ [27] and a similar decrease has been repeatedly demonstrated in individuals with DS in their sixth decade, compared to age-matched controls [28]. In addition, an agedependent decrease of ELISA-measured $A \beta_{1-42}$ levels in CSF has been observed in patients with DS between 21 and 61 years of age with the highest levels found in the youngest individual. The concentrations then decreased with age accompanied by an expected acceleration of plaque pathology [18]. This $A \beta_{1-42}$ decrease has been suggested to be due to the accelerated $A \beta$ accumulation in the brain leading to drainage of $A \beta$ from CSF with declining $A \beta$ levels as a consequence. These observations fit well with the results from this study where the patients were followed during their first 4 years of life when deposition of $A \beta$ into plaques is expected to be low and thus the patients display increasing levels of $A \beta$ in CSF. There was no indication of a longitudinal decrease in the $A \beta_{1-42} / A \beta_{1-40}$ ratio in these individuals, where a lowering of the ratio is used as a marker of enhanced risk of developing $\mathrm{AD}[16,29]$. This further emphasizes that studies of $A \beta$ in CSF during early childhood of patients with DS represent prestages of AD pathology.

There is emerging evidence of oligomeric $A \beta$ as the toxic molecules involved early in the pathogenesis (reviewed in Walsh and Selkoe [30]) and oligomeric $A \beta$ has been shown to exist in CSF [31-33]. In addition, it has been observed that aggregation of $A \beta$ into oligomeric and fibrillar species leads to a decline in $A \beta_{1-42}$ levels when measured by ELISA [34]. This makes the observation that $A \beta_{1-42}$ levels measured by Western blot and levels measured by xMAP technology display directly opposite patterns in young individuals with DS very interesting. While Western blot-measured $A \beta_{1-42}$ levels increase over time, xMAP-measured levels decrease (fig. 2), which could be explained by methodological differences, i.e. 
while Western blot is a denaturing method, xMAP analysis is made under native conditions. This phenomenon has been observed earlier and has been suggested to be due to epitope masking, caused both by $\mathrm{A} \beta$ aggregation and $A \beta$ binding to other proteins, leading to underestimated $A \beta$ levels when performing native analyses [34, 35]. Interestingly, in cell and animal models harboring the aggregation-prone Arctic APP mutation [36], this divergence in soluble $A \beta$ levels measured by Western blot and ELISA has been shown to be caused by the formation of soluble $A \beta$ oligomers [37]. Hence, the observed decrease in the DS infants, measured by the XMAP technology in this study, might be due to the presence of soluble oligomeric $A \beta$.

A marked elevation of both t-tau and p-tau in CSF can be used to distinguish sporadic AD cases from healthy individuals [38] and similar elevations of t-tau have been observed in studies of adult DS patients [18, 39]. However, the very young individuals with DS in this study displayed decreased levels of $\mathrm{t}$-tau in CSF during their first 4 years of life (fig. 3a), while levels of p-tau remained virtually unchanged (fig. 3b). Increasing levels of tau in CSF have been shown to correlate with frequency of neurofibrillary tangles in the $\mathrm{AD}$ brain [40], and since the patients with DS in this study were very young and most likely did not have either a cortical $A \beta$ or tau pathology [17], increasing levels of tau were not expected. The decreasing levels of tau are not believed to be due to maturation of the blood-brain barrier since the blood-brain barrier is thought to have reached full maturation at birth. Protein levels in CSF, including levels of tau and $\mathrm{p}$ tau, during early childhood have not been studied exten- sively, though there are results indicating that there is an age-dependent change before 3 months of age after which levels become more stable during childhood [41]. Levels of p-tau have been shown to vary during development with decreasing levels with age [41]. The lack of change in the present study may be explained by the relatively short follow-up time. The early overproduction of $A \beta$ without an increase in $p$-tau supports the suggestion of $A \beta$ as the driving force in $\mathrm{AD}$ pathology and the hyperphosphorylation of tau, which leads to tangle formation, as a downstream event [42].

To conclude, children with DS exhibit increasing CSF levels of $A \beta$ during their first 4 years of life, probably due to the trisomy of APP and low aggregation rate of $A \beta$ at this early age. The inconsistency of $A \beta_{1-42}$ levels measured by two different methods indicates formation of soluble $A \beta$ aggregates, oligomers, early in life. The non$\mathrm{AD}$-indicative $\mathrm{A} \beta$ pattern found could indicate that sporadic $A D$ is caused by an impaired $A \beta$ clearance, rather than an overproduction of $A \beta$; $p$-tau and $t$-tau show no AD-like changes during early childhood, probably due to the lack of neurofibrillary tangle formation in the brain of these young individuals.

\section{Acknowledgements}

This work was supported by grants from Hjärnfonden and Bertil Hållstens forskningsstiftelse (L.L.), Alzheimerfonden (H.E., L.L.), The Swedish Research Council (projects 2003-5546, L.L.; 09748, G.A., J.G.), Pfizer AB (J.G., G.A.), The Carl Tesdorph Foundation (G.A.) and Sävstaholm Society (G.A., J.G.).

\section{References}

1 Olson MI, Shaw CM: Presenile dementia and Alzheimer's disease in mongolism. Brain 1969;92:147-156.

2 Mann DM, Yates PO, Marcyniuk B: Alzheimer's presenile dementia, senile dementia of Alzheimer type and Down's syndrome in middle age form an age-related continuum of pathological changes. Neuropathol Appl Neurobiol 1984;10:185-207.

3 Motte J, Williams RS: Age-related changes in the density and morphology of plaques and neurofibrillary tangles in Down syndrome brain. Acta Neuropathol (Berl) 1989;77:535546.

4 Wisniewski KE, Dalton AJ, McLachlan C, Wen GY, Wisniewski HM: Alzheimer's disease in Down's syndrome: clinicopathologic studies. Neurology 1985;35:957-961.
5 Hardy JA, Higgins GA: Alzheimer's disease: the amyloid cascade hypothesis. Science 1992;256:184-185.

6 Kang J, Lemaire HG, Unterbeck A, Salbaum JM, Masters CL, Grzeschik KH, Multhaup G, Beyreuther K, Muller-Hill B: The precursor of Alzheimer's disease amyloid A4 protein resembles a cell-surface receptor. Nature 1987;325:733-736.

7 Head E, Lott IT: Down syndrome and betaamyloid deposition. Curr Opin Neurol 2004; 17:95-100.

8 Prasher VP, Farrer MJ, Kessling AM, Fisher EM, West RJ, Barber PC, Butler AC: Molecular mapping of Alzheimer-type dementia in Down's syndrome. Ann Neurol 1998;43: 380-383.
9 Wiltfang J, Esselmann H, Bibl M, Smirnov A, Otto M, Paul S, Schmidt B, Klafki HW, Maler M, Dyrks T, Bienert M, Beyermann M, Ruther E, Kornhuber J: Highly conserved and disease-specific patterns of carboxyterminally truncated Abeta peptides 1-37/38/39 in addition to 1-40/42 in Alzheimer's disease and in patients with chronic neuroinflammation. J Neurochem 2002;81:481-496.

10 Hansson O, Zetterberg H, Buchhave P, Londos E, Blennow K, Minthon L: Association between CSF biomarkers and incipient Alzheimer's disease in patients with mild cognitive impairment: a follow-up study. Lancet Neurol 2006;5:228-234. 
11 Anneren G, Tuvemo T, Carlsson-Skwirut C, Lonnerholm T, Bang P, Sara VR, Gustafsson $\mathrm{J}$ : Growth hormone treatment in young children with Down's syndrome: effects on growth and psychomotor development. Arch Dis Child 1999;80:334-338.

12 Folin M, Baiguera S, Conconi MT, Pati T, Grandi C, Parnigotto PP, Nussdorfer GG: The impact of risk factors of Alzheimer's disease in the Down syndrome. Int J Mol Med 2003;11:267-270.

13 Cavani S, Tamaoka A, Moretti A, Marinelli L, Angelini G, Di Stefano S, Piombo G, Cazzulo V, Matsuno S, Shoji S, Furiya Y, Zaccheo D, Dagna-Bricarelli F, Tabaton M, Mori $\mathrm{H}$ : Plasma levels of amyloid beta 40 and 42 are independent from ApoE genotype and mental retardation in Down syndrome. Am J Med Genet 2000;95:224-228.

14 Mehta PD, Capone G, Jewell A, Freedland RL: Increased amyloid beta protein levels in children and adolescents with Down syndrome. J Neurol Sci 2007;254:22-27.

15 Olsson A, Vanderstichele H, Andreasen N, De Meyer G, Wallin A, Holmberg B, Rosengren L, Vanmechelen E, Blennow K: Simultaneous measurement of beta-amyloid (1-42), total tau, and phosphorylated tau (Thr181) in cerebrospinal fluid by the xMAP technology. Clin Chem 2005;51:336-345.

16 Fukuyama R, Mizuno T, Mori S, Nakajima K, Fushiki S, Yanagisawa K: Age-dependent change in the levels of Abeta40 and Abeta42 in cerebrospinal fluid from control subjects, and a decrease in the ratio of Abeta 42 to Abeta40 level in cerebrospinal fluid from $\mathrm{Alz}$ heimer's disease patients. Eur Neurol 2000; 43:155-160.

17 Teller JK, Russo C, DeBusk LM, Angelini G, Zaccheo D, Dagna-Bricarelli F, Scartezzini P, Bertolini S, Mann DM, Tabaton M, Gambetti P: Presence of soluble amyloid beta-peptide precedes amyloid plaque formation in Down's syndrome. Nat Med 1996;2:93-95.

18 Tapiola T, Soininen H, Pirttila T: CSF tau and Abeta42 levels in patients with Down's syndrome. Neurology 2001;56:979-980.

19 Jensen M, Schroder J, Blomberg M, Engvall B, Pantel J, Ida N, Basun H, Wahlund LO, Werle E, Jauss M, Beyreuther K, Lannfelt L, Hartmann T: Cerebrospinal fluid A beta42 is increased early in sporadic Alzheimer's disease and declines with disease progression. Ann Neurol 1999;45:504-511.

20 Motter R, Vigo-Pelfrey C, Kholodenko D, Barbour R, Johnson-Wood K, Galasko D, Chang L, Miller B, Clark C, Green R: Reduction of beta-amyloid peptide42 in the cerebrospinal fluid of patients with Alzheimer's disease. Ann Neurol 1995;38:643-648.
21 Andreasen N, Vanmechelen E, Vander stichele $\mathrm{H}$, Davidsson P, Blennow K: Cerebrospinal fluid levels of total-tau, phosphotau and a beta 42 predicts development of Alzheimer's disease in patients with mild cognitive impairment. Acta Neurol Scand 2003;179(suppl):47-51.

22 Bartha JL, Soothill PW: Plasma amyloid beta protein 1-42 levels in fetuses with Down syndrome. Early Hum Dev 2005;81:351354.

23 Schupf N, Patel B, Silverman W, Zigman WB, Zhong N, Tycko B, Mehta PD, Mayeux $\mathrm{R}$ : Elevated plasma amyloid beta-peptide 142 and onset of dementia in adults with Down syndrome. Neurosci Lett 2001;301: 199-203.

24 Mehta PD, Mehta SP, Fedor B, Patrick BA, Emmerling M, Dalton AJ: Plasma amyloid beta protein 1-42 levels are increased in old Down syndrome but not in young Down syndrome. Neurosci Lett 2003;342:155-158.

25 Rovelet-Lecrux A, Hannequin D, Raux G, Le Meur N, Laquerriere A, Vital A, Dumanchin C, Feuillette S, Brice A, Vercelletto M, Dubas F, Frebourg T, Campion D: APP locus duplication causes autosomal dominant early-onset Alzheimer disease with cerebral amyloid angiopathy. Nat Genet 2006;38:24-26.

26 Höglund K, Syversen S, Lewczuk P, Wallin A, Wiltfang J, Blennow K: Statin treatment and a disease-specific pattern of beta-amyloid peptides in Alzheimer's disease. Exp Brain Res 2005;164:205-214.

27 Andreasen N, Minthon L, Davidsson P, Vanmechelen E, Vanderstichele H, Winblad B, Blennow K: Evaluation of CSF-tau and CSFAbeta42 as diagnostic markers for Alzheimer disease in clinical practice. Arch Neurol 2001;58:373-379.

28 Tamaoka A, Sekijima Y, Matsuno S, Tokuda T, Shoji S, Ikeda SI: Amyloid beta protein species in cerebrospinal fluid and in brain from patients with Down's syndrome. Ann Neurol 1999;46:933.

29 Hansson O, Zetterberg H, Buchhave P, Andreasson U, Londos E, Minthon L, Blennow K: Prediction of Alzheimer's disease using the CSF Abeta42/Abeta40 ratio in patients with mild cognitive impairment. Dement Geriatr Cogn Disord 2007;23:316-320.

30 Walsh DM, Selkoe DJ: Abeta oligomers - A decade of discovery. J Neurochem 2007;101: 1172-1184.

31 Georganopoulou DG, Chang L, Nam JM, Thaxton CS, Mufson EJ, Klein WL, Mirkin CA: Nanoparticle-based detection in cerebral spinal fluid of a soluble pathogenic biomarker for Alzheimer's disease. Proc Natl Acad Sci USA 2005;102:2273-2276.

32 Pitschke M, Prior R, Haupt M, Riesner D: Detection of single amyloid beta-protein aggregates in the cerebrospinal fluid of $\mathrm{Alz}$ heimer's patients by fluorescence correlation spectroscopy. Nat Med 1998;4:832-834.
33 Santos AN, Torkler S, Nowak D, Schlittig C, Goerdes M, Lauber T, Trischmann L, Schaupp M, Penz M, Tiller FW, Bohm G: Detection of amyloid-beta oligomers in human cerebrospinal fluid by flow cytometry and fluorescence resonance energy transfer. J Alzheimers Dis 2007;11:117-125.

34 Stenh C, Englund H, Lord A, Johansson AS, Almeida CG, Gellerfors P, Greengard P, Gouras GK, Lannfelt L, Nilsson LN: Amyloid-beta oligomers are inefficiently measured by enzyme-linked immunosorbent assay. Ann Neurol 2005;58:147-150.

35 Bibl M, Esselmann H, Otto M, Lewczuk P, Cepek L, Ruther E, Kornhuber J, Wiltfang J: Cerebrospinal fluid amyloid beta peptide patterns in Alzheimer's disease patients and nondemented controls depend on sample pretreatment: indication of carrier-mediated epitope masking of amyloid beta peptides. Electrophoresis 2004;25:2912-2918.

36 Nilsberth C, Westlind-Danielsson A, Eckman CB, Condron MM, Axelman K, Forsell C, Stenh C, Luthman J, Teplow DB, Younkin SG, Naslund J, Lannfelt L: The 'Arctic' APP mutation (E693G) causes Alzheimer's disease by enhanced Abeta protofibril formation. Nat Neurosci 2001;4:887-893.

37 Englund H, Sehlin S, Johansson A-S, Nilsson LNG, Gellerfors P, Paulie S, Lannfelt L, Ekholm Pettersson F: Sensitive ELISA detection of amyloid- $\beta$ protofibrils in biological samples. J Neurochem, in press.

38 Blennow K, Hampel H: CSF markers for incipient Alzheimer's disease. Lancet Neurol 2003;2:605-613.

39 Mehta PD, Patrick BA, Dalton AJ, Aisen PS, Emmerling ME, Sersen EA, Wisniewski HM: Increased levels of tau-like protein in patients with Down syndrome. Neurosci Lett 1999;275:159-162.

40 Tapiola T, Overmyer M, Lehtovirta $M$ Helisalmi S, Ramberg J, Alafuzoff I, Riekkinen P Sr, Soininen H: The level of cerebrospinal fluid tau correlates with neurofibrillary tangles in Alzheimer's disease. Neuroreport 1997;8:3961-3963.

41 Van Gool SW, De Meyer G, Van de Voorde A, Vanmechelen E, Vanderstichele H: Neurotoxicity marker profiles in the CSF are not age-dependent but show variation in children treated for acute lymphoblastic leukemia. Neurotoxicology 2004;25:471-480.

42 Oddo S, Caccamo A, Kitazawa M, Tseng BP, LaFerla FM: Amyloid deposition precedes tangle formation in a triple transgenic model of Alzheimer's disease. Neurobiol Aging 2003;24:1063-1070.

Englund/Annerén/Gustafsson/Wester/ Wiltfang/Lannfelt/Blennow/Höglund 